\title{
Antioxidant activity of the aerial parts and the flowers of Chiliotrichum diffusum (G. Forst.) Kuntze (Asteraceae), a medicinal plant used by the Onas
}

\author{
Atividade antioxidante das partes aéreas e flores da \\ Chiliotrichum diffusum (G. Forst.) Kuntze (Asteraceae), \\ uma planta medicinal usada pelos Onas
}

Recebido em: 05/12/2018 Aceito em: 08/06/2019
Sandra Marcela Alcalde BAHAMONDE' ${ }^{1}$, Carlos Alberto TAIRA²; María Luján FLORES ${ }^{1}$; Osvaldo León CÓRDOBA ${ }^{1}$ ${ }^{1}$ Facultad de Ciencias Naturales y Ciencias de la Salud, Universidad Nacional de la Patagonia San Juan Bosco, Km 4, s/n, 9000, Comodoro Rivadavia, Chubut, Argentina. ${ }^{2}$ Facultad de Farmacia y Bioquímica, Universidad de Buenos Aires, Junín 956, 1113, Ciudad Autónoma de Buenos Aires, Argentina. E-mail:okylola@gmail.com

\section{ABSTRACT}

The antioxidant capacity of Chiliotrichum diffusum, a medicinal plant used in the traditional medicine of the Onas (original people of Patagonia), was studied by using the DPPH method, to explain the properties associated to the traditional use of this species. Ethyl ether (or dichloromethane from decoction of the flowers) and the ethyl acetate fraction from ethanol and aqueous extracts, showed free radical scavenging capacity on DPPH•. The results of the quantitative determination of this activity in ethyl ether and the ethyl acetate fraction from ethanol extract of aerial parts showed $\mathrm{SC}_{50}$ of 5.2 and $3.5 \mu \mathrm{g} / \mathrm{mL}$, respectively. Dichloromethane and ethyl acetate fractions of the aqueous extracts from flowers showed $\mathrm{SC}_{50}$ values of 35.0 and $9.5 \mu \mathrm{g} / \mathrm{mL}$. The principal flavonoids found were kaempferol, quercetin and their derivates. These results showed a relation of the phenols evidenced in the aerial parts and flowers and the antioxidant activity; also explained, at least partially, the medicinal properties described, and the use of this plant in the traditional medicine of the Onas.

Keywords: antioxidant; Asteraceae; Chiliotrichum diffusum; Onas; Patagonia

\section{RESUMO}

A capacidade antioxidante de Chiliotrichum diffusum, uma planta medicinal utilizada pelos Onas (povos originários da Patagônia), foi estudada usando o método do DPPH, com o objetivo de explicar as propriedades associadas ao uso tradicional dessa espécie. As frações éter etílico, diclorometano, e acetato de etila, mostraram uma alta capacidade de sequestro de radicais livres DPPH•. Os resultados da determinação quantitativa da capacidade de sequestro de radicais livres das frações éter etílico e acetato de etila do extrato etanólico das partes aéreas (EE-HOL e EA-HOL) mostraram valores de $\mathrm{SC}_{50}$ de 5,2 e 3,5 $\mu \mathrm{g} / \mathrm{mL}$, respectivamente. As frações diclorometano e acetato de etila da decocção das flores (DM-DF e EA-DF) apresentaram $\mathrm{SC}_{50}$ de 35,0 e 9,5 $\mathrm{g} / \mathrm{mL}$, respectivamente. Os principais flavonoides identificados foram kaempferol, quercetina e seus derivados. Os resultados mostram a relação com os fenois evidenciados nas partes aéreas e flores e a atividade antioxidante; também podem explicar parcialmente as propriedades medicinais descritas e seu uso na medicina tradicional dos Onas.

Palavras-chave: antioxidante; Asteraceae; Chiliotrichum diffusum; Onas; Patagônia 


\section{INTRODUCTION}

Chiliotrichum diffusum (G. Forst.) Kuntze (Asteraceae), "mata negra", "kóor" (in shélknam or Ona language), a medicinal plant used in the traditional medicine of the Onas (original people of Patagonia), inhabits the southwest of Argentina. The flowers of this species have been used by Onas to "clarify the sight" (1); also native inhabitants of Patagonia Austral have been used the aerial parts in cure rituals (2). In Chile, this plant has been reported to be good for the memory and for treating headache and cramps; also has been used as a component of creams or oils, sometimes mixed with Matricaria chamomilla (Asteraceae) to treat varicose and cramps (3).

A previous study using Artemia salina cytotoxicity bioassay showed that the ethanol crude extract and the ethyl acetate and water fractions of Chiliotrichum diffusum flowers presented cytotoxic activity $\left(\mathrm{LC}_{50}<20 \mu \mathrm{g} / \mathrm{mL}\right.$ ) (4). Flavonoids, tannins and carbohydrates were detected in aerial parts and flowers (5). The main flavonoid were flavones, dihydroflavonols, flavonols and flavonoid glycosides $(5,6)$. These compounds can scavenge free radicals and inhibit autoxidation reactions (7), which would explain some of the uses and properties of this plant. Phenolic compounds are the most important natural antioxidant metabolites (8). Flavonoids have shown anticancer, cardiotonic, antithrombotic, vascular, hypocholesterolemic and hepatoprotective properties (9).

In this context, the aim of this work was to study the antioxidant activity of the fractions of ethanol extract from aerial parts and the fractions of aqueous extract from $C$. diffusum flowers, by measuring the $\mathrm{SC}_{50}$ (concentration sufficient to obtain $50 \%$ of maximum scavenging capacity) and flavonoid composition, to try to explain the properties associated with the traditional use of this species.

\section{MATERIALS AND METHODS}

General. UV spectra were recorded on a Varian's Cary 50 UV-Vis spectrophotometer. Planar Chromatography (PC) was performed on Whatman
$\mathrm{N}^{\circ} 1$ or Whatman $\mathrm{N}^{\circ} 3 \mathrm{MN}$ paper. Detection was achieved by UV light at 254 and $365 \mathrm{~nm}$.

Plant material. Aerial parts and flowers of Chiliotrichum diffusum (Asteraceae) were collected in 28 de Noviembre city (Santa Cruz, Argentina) in Summer of 2006. A voucher specimen was deposited at the Herbario Regional Patagónico UNPSJB (HRP N ${ }^{\circ} 5305$ ).

Extraction and fractionation. Air-dried and powdered total aerial parts were extracted with ethanol for $48 \mathrm{~h}$ at room temperature. Dried total extract was resuspended in water and then subsequently partitioned by liquid-liquid extraction between ethyl ether (EE-HOL) and ethyl acetate (EA-HOL). Similar partitioning was carried out for decoction (water extract for $20 \mathrm{~min}$ at $100{ }^{\circ} \mathrm{C}$ ) of the isolated flowers to obtain dichloromethane (DM-DF) and ethyl acetate (EA-DF). Figure 1 shows the outline of the carried out work.

Identification of main compounds. All the fractions were analyzed using chromatography profiles on Whatman $\mathrm{N}^{\circ} 1$ paper with Forestal reagent $\left(\mathrm{HCl}-\mathrm{AcOH}-\mathrm{H}_{2} \mathrm{O}, 3: 30: 10\right), \mathrm{AcOH} 15 \%$ and water, to determine the flavonoid and other phenolic groups. The compounds were detected by UV light (254 and $365 \mathrm{~nm}$ ) without and with the exposition of $\mathrm{NH}_{3}$ vapors.

The main compounds were separated by preparative chromatography on paper Whatman $\mathrm{N}^{\circ}$ $3 \mathrm{MN}$. In each case, the spectra of these compounds were obtained by UV-Vis spectrophotometry in methanol. The metabolites were identified by comparison with standards and bibliographic data.

Antioxidant activity by the 1,1-diphenyl2-picrylhydrazyl (DPPH) method. The DPPH method is based on the reduction of alcoholic DPPH solution in the presence of a hydrogen donating antioxidant (10). DPPH solution presents a strong absorption band at $517-518 \mathrm{~nm}$, appearing as a deep violet color. The absorption decrease is stoichiometric concerning the degree of reduction. The remaining DPPH, measured after a certain time, inversely corresponds to the radical scavenging activity of the antioxidant. This method was used to assess the antioxidant activity of all the fractions.

The radical scavenging activity was assessed as follows: $1.5 \mathrm{~mL}$ of each fraction $(0.433 \mathrm{mg} / \mathrm{mL})$ 
was mixed with $1 \mathrm{~mL}$ of $0.3 \mathrm{mM}$ DPPH ethanol solution. Butylated hydroxy toluene (BHT, 0.039 $\mathrm{mg} / \mathrm{mL}$ ) was used as a positive control, and ethanol was used as a negative control. After shaking the mixture, absorbance was measured at $518 \mathrm{~nm}$ after 30 min of incubation in the darkness. Inhibition of free radical DPPH in percent (Inhibition \%) was calculated as follows:

\section{Inhibition $\%=($ A blank - A sample $) \times 1 / A$ blank x 100}

Where:

A blank is the absorption of the control reaction (containing all the reagents except the test compound

A sample is the absorbance of the test fraction.

Values are presented as the mean \pm standard deviation of three determinations.

$\mathbf{S C}_{\mathbf{5 0}}$ determination. Samples were dissolved in ethanol to obtain a concentration of $1 \mathrm{mg} / \mathrm{mL}$ and further diluted to appropriate concentrations. The experiments were performed in triplicate. Negative control was prepared with DPPH $(0.8 \mathrm{~mL})$ and ethanol $(2 \mathrm{~mL})$. Also, a blank sample for all the dilutions was prepared with sample $(2 \mathrm{~mL})$ and ethanol $(0.8 \mathrm{~mL})$. The samples and controls were incubated for $30 \mathrm{~min}$ in the dark after aggregation of DPPH $(0.8 \mathrm{~mL})$ in all of them and the absorbance was measured at $518 \mathrm{~nm}$. The obtained data were used to determine the sample concentration required to scavenge $50 \%$ of the $\mathrm{DPPH} \bullet$ free radicals $\left(\mathrm{SC}_{50}\right)$. The $\mathrm{SC}_{50}$ value for each sample was calculated based on the linear regression of the percentage of remaining DPPH radical against the sample concentration. For each dilution of the samples, the scavenging $\%$ was determined as follows:

\section{Scavenging $\%=100-[($ A sample - A blank sample) x 1/ A control] x 100}

Where:

A blank is the absorption of the control reaction (containing all the reagents except the test compound

A sample is the absorbance of the test fraction.

A control is the absorbance of the compound used as reference.

Values are presented as the mean \pm standard deviation of three determinations..

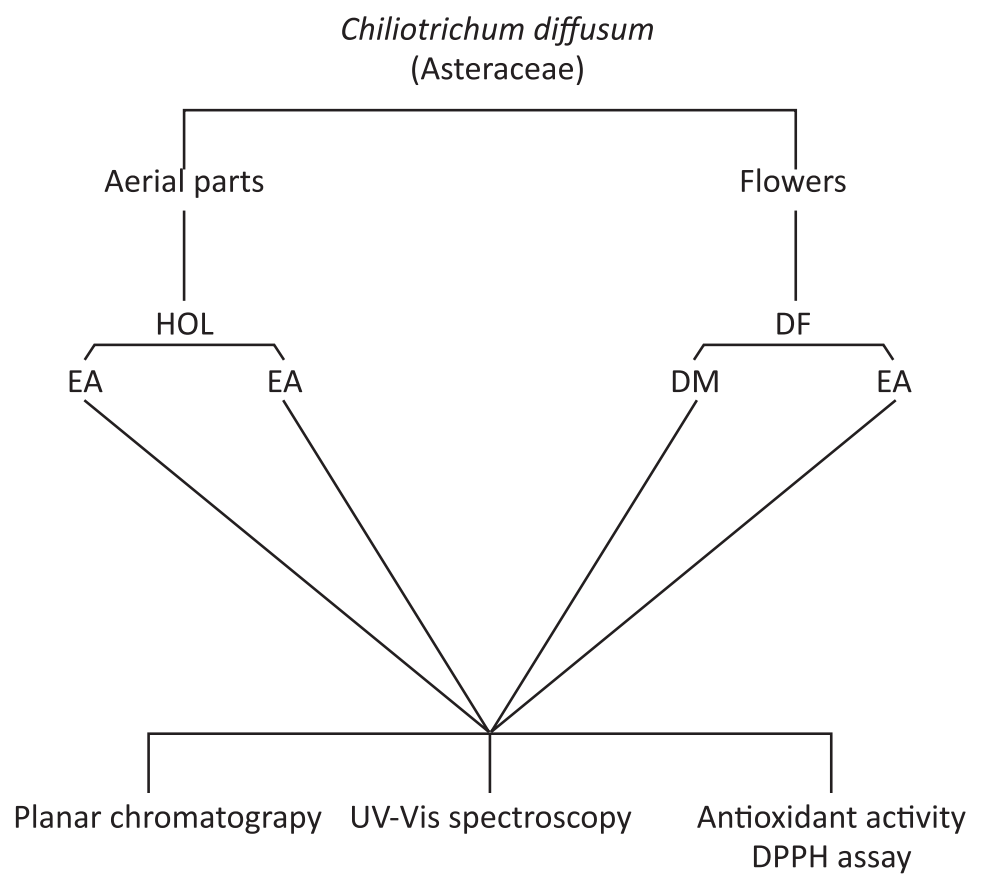

Figure 1. Scheme of the work carried out with Chiliotrichum diffusum (Asteraceae). 


\section{RESULTS AND DISCUSSION}

The ethanol extract of aerial parts (HOL) and the aqueous extract (decoction) of the flowers (DF) were obtained with yields of $23.84 \%$ and $35.96 \%$, respectively. The extracts were partitioned with solvents; the ethyl ether (EE-HOL), dichloromethane (DM-DF) and ethyl acetate (EAHOL, EA-DF) fractions were analyzed to determine flavonoid constituents and antioxidant activity (Figure 1). Flavonoids were identified using paper chromatography and UV-Vis spectrophotometry. The main compounds are shown in Table 1.

The ethyl ether and dichloromethane fractions presented apigenin (1); EE-HOL also showed methyl derivates. The analyses of UV-Vis spectra corroborated the presence of apigenin (1) in DMDF, but also showed gossypin (2), sexangularetin (3, herbacetin-8-methyl ether), morin (4), isorhamnetin (5), and quercetin (6) in EE-HOL.

In the ethyl acetate from ethanol (EAHOL) and water extracts (EA-DF), flavones, dihydroflavonols, flavone 7-O-monoglycoside, and flavonol 3-O-monoglycoside were identified. EA-HOL showed vitexin (7), quercetin methyl ether, kaempferol-O-glycoside and apigenin-7-Oglucoside (8, apigetrin). EA-DF showed myricetin (9), kaempferol (10), kaempferol-7-methyl ether (11, rhamnocitrin), myricetin-3-O-arabinoside (12) and kaempferol-3-O-galactoside (13, trifolin).<smiles>[R5]c1cc(O)c2c(=O)c([R1])c(-c3cc([R6])c(O)c([R3])c3)oc2c1</smiles>

$\begin{array}{llllll} & \mathrm{R} 1 & \mathrm{R} 2 & \mathrm{R} 3 & \mathrm{R} 4 & \mathrm{R} 5 \\ \text { 1 - apigenin } & \mathrm{H} & \mathrm{H} & \mathrm{H} & \mathrm{OH} & \mathrm{OH} \\ \text { 4 - morin } & \mathrm{OH} & \mathrm{OH} & \mathrm{OH} & \mathrm{OH} & \mathrm{OH} \\ \text { 5 - isorhamnetin } & \mathrm{OH} & \mathrm{H} & \mathrm{OMe} & \mathrm{OH} & \mathrm{OH} \\ \text { 6 - quercetin } & \mathrm{OH} & \mathrm{H} & \mathrm{OH} & \mathrm{OH} & \mathrm{OH} \\ \text { 8 - apigetrin } & \mathrm{H} & \mathrm{H} & \mathrm{H} & \mathrm{Oglu} & \mathrm{OH} \\ \text { 9 - myricetin } & \mathrm{OH} & \mathrm{OH} & \mathrm{OH} & \mathrm{OH} & \mathrm{OH} \\ 10 \text { - kaempferol } & \mathrm{OH} & \mathrm{H} & \mathrm{H} & \mathrm{OH} & \mathrm{OH} \\ \text { 11- rhamnocitrin } & \mathrm{OH} & \mathrm{H} & \mathrm{H} & \mathrm{OH} & \mathrm{OMe} \\ 12 \text { - myricetin-3-ara } & \mathrm{Oara} & \mathrm{OH} & \mathrm{OH} & \mathrm{OH} & \mathrm{OH} \\ 13 \text { - trifolin } & \mathrm{Ogal} & \mathrm{H} & \mathrm{H} & \mathrm{OH} & \mathrm{OH} \\ 14 \text { - luteolin } & \mathrm{H} & \mathrm{H} & \mathrm{OH} & \mathrm{OH} & \mathrm{OH}\end{array}$<smiles>[R2]c1cc(-c2oc3c([R1])c(O)cc(O)c3c(=O)c2O)ccc1O</smiles><smiles>[R2]c1cc([C@H]2Oc3cc(O)cc(O)c3C(=O)[C@@H]2[R1])ccc1O</smiles>

$\begin{array}{lll} & \text { R1 } & \text { R2 } \\ \text { 2- gossipin } & \text { O-glu } & \mathrm{OH} \\ \text { 3 - sexangularetin } & \text { O-Me } & \mathrm{H} \\ \text { 7 - vitexin } & \text { glu } & \mathrm{H}\end{array}$


The effect on the free radical scavenging ability was determined through the DPPH method, one of the most effective, reactive, reliable, simple and reproducible in vitro method to evaluate the activity of single compounds or plant extracts (1113). This method is also independent of the substrate polarity. Therefore, was used to evaluate the ethyl ether and dichloromethane (EE-HOL, DM-DF) and ethyl acetate (EA-HOL, EA-DF) fractions from the ethanol and decoction extracts of $C$. diffusum. All the fractions showed strong antioxidant activity. In all the cases, the fractions showed a high percentage of inhibition of $\mathrm{DPPH} \bullet$ radical (Table 2). The EE-HOL and EA-HOL fractions showed the highest percentages of inhibition, $\approx 87$ and $91 \%$ respectively, and EE-HOL, EA-HOL and EA-DF showed important antioxidant activity with $\mathrm{SC}_{50}$ values of 5.2, 3.5 and $9.5 \mu \mathrm{g} / \mathrm{mL}$ respectively (Table 2).

The most representative natural antioxidants are metabolites like carotenoids, ascorbic acid, tocopherols, and polyphenols (fundamentally flavonoids), and can protect the human body from free radicals retarding the progress of many chronic diseases (14). Polyphenols have received increasing attention from the pharmacological and therapeutic point of view, because of some interesting biological activities, such as free radical scavenging. In recent years, flavonoids have been widely recognized as a major class of secondary metabolites with antioxidant properties due to their ability to scavenge free radicals. This property is due to several different mechanisms, such as scavenging of free radicals, chelation of metal ions such as iron and copper, and inhibition of enzymes responsible for a free-radical generation $(15,16)$. Depending on the structure, flavonoids can scavenge practically all known reactive oxygen species (ROS), such as superoxide anions, hydrogen peroxide, hydroxyl radicals, singlet oxygen, alkoxy, aroxyl and peroxyl radicals, and alkyl-, aryl-, and nitrogenderived radicals. Therefore, flavonoids may protect biosystems against free-radical attack, which may result in cancer and coronary heart disease.

Table 1. Flavonoids from Chiliotrichum diffusum

\begin{tabular}{|c|c|c|c|}
\hline Fraction & Flavonoid & Rf & $\lambda_{\text {máx MeOH }}(\mathrm{nm})$ \\
\hline \multirow{4}{*}{ EE-HOL } & \multicolumn{3}{|c|}{$\mathrm{AcOH}^{\mathrm{a}}$} \\
\hline & gossypin (2) & 0.42 & 260,275383 \\
\hline & herbacetin-8-methyl-ether (3) & 0.67 & $262,273,322,375$ \\
\hline & isorhamnetin (5) & 0.83 & $257,265,370$ \\
\hline \multirow{5}{*}{ EA-HOL } & \multicolumn{3}{|c|}{ Forestal reagent $t^{b}$} \\
\hline & vitexin (7) & 0.84 & $268,273,339$ \\
\hline & quercetin-methyl ether & 0.83 & 261,349 \\
\hline & kaempferol-O-glucoside & 0.80 & 248,325 \\
\hline & apigenin-7-O-glucoside (8) & 0.78 & 267,333 \\
\hline \multirow{3}{*}{ DM-DF } & \multicolumn{3}{|c|}{$\mathrm{AcOH}^{\mathrm{a}}$} \\
\hline & apigenin (1) & 0.62 & $267-270,332$ \\
\hline & flavone-methyl-ether & 0.79 & 275,315 \\
\hline \multirow{7}{*}{ EA-DF } & \multicolumn{3}{|c|}{ Forestal reagent $\mathrm{t}^{\mathrm{b}}$} \\
\hline & myricetin (9) & 0.27 & 254,374 \\
\hline & kaempferol (10) & 0.59 & 266,367 \\
\hline & kaempferol-7-methyl-ether (11) & 0.80 & 258,371 \\
\hline & \multicolumn{3}{|c|}{ Water } \\
\hline & kaempferol-3-O-galactoside (13) & 0.08 & 265,356 \\
\hline & myricetin-3-O-arabinoside (12) & 0.02 & 264,358 \\
\hline
\end{tabular}

${ }^{\mathrm{a}} \mathrm{AcOH}: 15 \%$; ${ }^{\mathrm{b}}$ Forestal reagent: $\mathrm{HCl}-\mathrm{AcOH}-\mathrm{H}_{2} \mathrm{O}$ (3:30:10) 
Radical scavenging activity of flavonoids toward DPPH radicals depends on the number of hydroxyl groups in the B ring, and the higher the number of hydroxyl groups in the B ring, the higher the radical-scavenging potency of flavonoids. The C2-C3 double bond seems to have any contribution to the hydrogen-donating ability of flavonoids when B ring presents no hydroxyl group. Hydroxyl groups help to stabilize the aryloxyl radical after hydrogen donation in the process of scavenging (17). The most remarkable polyhydroxylated flavonoids are those that have a 3',4'-dihydroxy catechol system in the B ring, as is the case of luteolin (14), quercetin (6) and taxifolin (15), which show excellent inhibitory activity against DPPH radicals. Besides, some flavonoids with only one hydroxyl group (4'-hydroxyl), such as naringenin (16) and aromadendrin (17), have also been found to have inhibitory activity. Therefore, ortho-hydroxyl substitution, whether on the B ring or the A ring, are essential for the antiradical activity of flavonoids, and additional substitution seems to have no noticeable influence (18).

The activity of quercetin (6) and kaempferol (10) on DPPH radical scavenging is well-known $(18,19)$. In the present study, the antioxidant activity of aerial parts ethanol extracts and decoction of the flowers from $C$. diffusum was due to the presence of apigenin (1), isorhamnetin (5), quercetin (6), kaempferol (10), and monoglycosyl derivates (7-O-glycosylate) of apigenin and kaempferol (Table 1). These compounds present the necessary characteristics to support the obtained results.

Table 2. Antioxidant activity of the principal fractions from alcoholic and aqueous water extracts from Chiliotrichum diffusum (Asteraceae)

\begin{tabular}{|c|c|c|}
\hline Fraction & Inhibition (\%) & $\mathrm{SC}_{50}(\mu \mathrm{g} / \mathrm{mL})$ \\
\hline EE-HOL & $86.45 \pm 3.76$ & $5.2 \pm 0.54$ \\
\hline EA-HOL & $90.80 \pm 0.48$ & $3.5 \pm 1.31$ \\
\hline DM-DF & $62.88 \pm 6.80$ & $35.0 \pm 7.18$ \\
\hline EA-DF & $82.14 \pm 0.94$ & $9.5 \pm 1.68$ \\
\hline
\end{tabular}

The relationship between antioxidant activity and cytotoxic activity is due to the ability of these substances to prevent cellular damage.
ROS interact with polyunsaturated lipids of cell membranes, resulting in loss of fluidity and cell lysis due to lipid peroxidation. These species also interact on carbohydrates, altering the cellular functions such as those associated with the activity of interleukins and formation of prostaglandins, hormones and neurotransmitters. ROS also affect proteins by inactivation and unfolding, and interact with nucleic acids, causing mutagenesis and carcinogenesis.

The production of free radicals is thus associated with cell transformation, atherosclerosis, inflammatory diseases, memory loss, ageing (13).

It has been demonstrated that kaempferol (10) and derivatives (3-O-glycosyl) are related to cytotoxic and antioxidant effects. Also, other glycosyl derivatives of quercetin $(\boldsymbol{\sigma})$ and kaempferol (10) show both effects (20).

The results indicated a higher antioxidant activity of the EA-HOL fraction $\left(\mathrm{SC}_{50}=3.5 \mu \mathrm{g} / \mathrm{mL}\right)$ in comparison to the other fractions tested. Previous studies have also shown a strong cytotoxic activity of this fraction, with $\mathrm{LC}_{50}$ lower than $20 \mu \mathrm{g} / \mathrm{mL}$ (4). It can be inferred that the glycosylated derivative of kaempferol is one of the compounds responsible for both activities. The presence of apigetrin $(\boldsymbol{8}$, apigenin-7-O-glucoside) has also been showed (8). This compound presents high antioxidant and cytotoxic activity, due to the presence of 7-glycosylation, a saturated heterocyclic ring, and one $\mathrm{OH}$ group in the $\mathrm{B}$ ring (21).

EE-HOL and EA-HOL fractions from the ethanol extract from $C$. diffusum aerial parts exhibited higher antioxidant activity than natural antioxidants such as vitamin $\mathrm{C}$ and $\mathrm{E}\left(\mathrm{SC}_{50}=7.8\right.$ $\mu \mathrm{g} / \mathrm{mL}$ ) (19).

It has been reported an inverse relationship between antioxidant status and incidence of human diseases. Quercetin (6) presents antioxidant capacity, and ability to be in determined areas of cellular structures. Therefore, quercetin (6) can also inhibit lipooxygenases (LOX), cyclooxygenases (COX) and other enzyme systems involved in analgesic and inflammatory processes; and prostaglandins, are also involved in the proliferation of various types of cancer $(22,23)$. 
Previous in vivo pharmacological studies have demonstrated that the analgesic and antiinflammatory properties of the aqueous extract of flowers of C. diffusum are related to COX-Iand COX-II-mediated mechanisms that inhibit prostaglandin synthesis (6).

Substances evidenced in both extracts have been associated with cell transformation, atherosclerosis, inflammatory diseases, memory loss and ageing $(11,13)$. The obtained results are comparable to those for other medicinal plant extracts with high antioxidant activity $(24,25)$.

\section{CONCLUSION}

These results showed a relation with the flavonoids evidenced in the aerial parts (including flowers) and their antioxidant activity; also explain partially the medicinal properties described, and their use in the traditional medicine of the Onas.

Moreover, this study reveals that this species offers an interesting source of new antioxidant plant extracts, with potential for use in different fields (foods, cosmetics, pharmaceuticals).

\section{REFERENCES}

1. Vera JC. Uso alimentario de recursos vegetales entre cazadores recolectores de Bahía Laredo, Cabo Negro (Magallanes). Ann Inst Patagon 1993;22: 155-168.

2. Domínguez Díaz, E. Flora de interés etnobotánico usada por los pueblos originarios: Selk'nam, Kawésqar, Yagan y Haush en la Patagonia Austral. Dominguezia 2010;26(2):19-29.

3. Asociación Indígena Reuquen Willi Lafken de Punta Arenas. Catastro de la Flora nativa usada con fines medicinales por la Agrupación en la Reserva Nacional Magallanes en la Región de Magallanes y Antártica Chilena. Fondo de Protección de Ambiental - FPA 2010, Ministerio del Medio Ambiente, Chile; 2010.

4. Alcalde SM, Taira C, Höcht C, Córdoba OL, Flores ML. Fitoquímica y bioactividad de Chiliotrichum diffusum (Asteraceae) una especie nativa de la Patagonia Andina. Lat Am J Pharm 2010;29(2):284-288.

5. Alcalde SM, Taira C, Córdoba OL, Flores ML. Contribución al conocimiento farmacognóstico de Chiliotrichum diffusum (Asteraceae). Nat pat 2008;4(1):37-45.

6. Alcalde SM, Gorzalczany SB, Flores ML, Córdoba OL, Höcht C, Taira C. Evaluación farmacológica en relación al perfil fitoquímico del decocto de flores de Chiliotrichum diffusum (G. F.) K. (Asteraceae). BLACPMA 2007;6(6):315-316.

7. Burda S, Oleszek W. Antioxidant and antiradical activities of flavonoids. J Agric Food Chem 2001;49:2774-2779. DOI: $10.1021 /$ jf001413m.

8. Rosario M, Barrón-Yánez MR, García-Mateos MR, SotoHernández T, Colinas-León, Geoff Rey K. Flavonoides y actividad antioxidante de Calia secundiflora (Ort.) Yakovlev. Rev Fitotec Mex 2011;34:151-157.
9. Robards K, Prenzler D, Tucker G, Swatsitang P, Glover W. Phenolic compounds and their role in oxidative processes in fruits. Food Chem 1999;66:401-436. DOI: 10.1016/S0308-8146(99)00093-X.

10. Koleva II, van Beek TA, Linssen JPH, de Groot A, Evstatieva LN. Screening of plant extracts for antioxidant activity: a comparative study on three testing methods. Phytochem Anal 2002;13:8-17. DOI: 10.1002/pca.611.

11. Arantza Soler C. Estudio de la capacidad antioxidante y la biodisponibilidad de los compuestos fenólicos en el aceite de oliva. Primeras etapas en el desarrollo de un aceite de oliva funcional. [Thesis]. Universitat de Lleida, Escuela Técnica Superior de Ingeniería Agraria, Departamento de Tecnología de Alimentos. 2009.

12. Balestrin L, Dias JFG, Miguel OG, Dall'Stella DSG, Miguel MD. Contribuição ao estudo fitoquímico de Dorstenia multiformis Miquel (Moraceae) com abordagem em atividade antioxidante. Rev Bras Farmacogn 2008;18:230-235. DOI: 10.1590/S0102$695 X 2008000200016$.

13. Choi CW, Kim SC, Hwang SS, Choi BK, Ahn HJ, Lee MY, Park SH, Kim SK. Antioxidant activity and free radical scavenging capacity between Korean medicinal plants and flavonoids by assay-guided comparison. Plant Sci J 2002;163:1161-1168.

14. Lai LS, Chou ST, Chao WW. Studies on the antioxidative activities of Hsian-tsao (Mesona procumbens Hemsl) leaf gum. J Agric Food Chem 2001;49:963-968. DOI: 10.1021/jf001146k.

15. Acker SV, Balen GPV, Berg DJV, Vijgh WJF. Influence of iron chelation on the antioxidant activity of flavonoids. Biochem Pharmacol 1996;56:935-943. DOI: 10.1016/ S0006-2952(98)00102-6. 
16. Benavente-Garcia O, Castillo J, Marin FR, Ortuno A, Del Rio JA. Uses and properties of Citrus flavonoids. J Agric Food Chem 1997;45:4505-4515. DOI: 10.1021/ jf970373s.

17. Cao G, Sofic E, Prior RL. Antioxidant and prooxidant behavior of flavonoids: Structure-activity relationships. Free Radic Biol Med 1997;22:749-760.

18. Yokazawa T, Chen CP, Dong E, Tanaka T, Nonaka G-I, Nishioka I. Study on the inhibitory effect of tannins and flavonoids against the 1,1-diphenyl-2-picrylhydrazyl. Biochem Pharmacol 1998;56:213-222. DOI: 10.1016/ S0006-2952(98)00128-2.

19. Torres R, Faini F, Modak B, Urbina F, Labbe' C, Guerrero J. Antioxidant activity of coumarins and flavonols from the resinous exudate of Haplopappus multifolius. Phytochemistry 2006;67(10):984-987. DOI: 10.1016/j. phytochem.2006.03.016.

20. Susanti D, Sirat H, Ahmad F, Amt Ali R, Aimi N, Kitajima M. Antioxidant and cytotoxic flavonoids from the flowers of Melastoma malabathricum L.
Food Chem 2007;103:710-716. DOI: 10.1016/j. foodchem.2006.09.011.

21. Pekka Rahua J. The search for biological activity in finnish plant extracts containing phenolic compounds. [Dissertation]. Departament of Farmacognosy, Faculty of Science. University of Helsink. 2001.

22. Balkwill F, Coussens LM. Cancer: an inflammatory link. Nature 2004;431:405-406. DOI: 10.1038/431405a.

23. Fulton A, Kundu N. Targeting Prostaglandin E EP Receptors to Inhibit Metastasis. Cancer Res 2006;66:9794-9797. DOI: 10.1158/0008-5472.CAN-062067.

24. Pérez Trueba G. Los flavonoides: antioxidants o prooxidantes. Rev Cubana Invest Biomed 2003;22(1):4857.

25. Alonso J, Desmarchelier C. Plantas medicinales autóctonas de la Argentina. Bases científicas para su aplicación en atención primaria de la salud. Buenos Aires: Ediciones Fitociencia. 2006. 